\title{
Coral-rubble ridges as dynamic coastal features - short-term reworking and weathering processes
}

\author{
Michaela Spiske ${ }^{1,2}$ \\ ${ }^{1}$ Universität Trier, Geozentrum, Behringstr. 21, 54296 Trier, Germany \\ ${ }^{2}$ Westfälische Wilhelms-Universität, Institut für Geologie und Paläontologie, Corrensstr. 24, 48149 Münster, Germany \\ Correspondence to: Michaela Spiske (spiske@uni-muenster.de)
}

Received: 2 September 2015 - Revised: 17 January 2016 - Accepted: 19 February 2016 - Published: 29 February 2016

\begin{abstract}
A coral-rubble ridge built by storm waves at Anegada (British Virgin Islands) underwent remarkable changes in shape and weathering in a 23 -month period. The ridge is located along the island's north shore, in the lee of a fringing reef and a reef flat. This coarse-clast ridge showed two major changes between March 2013, when first examined, and February 2015, when revisited. First, a trench dug in 2013, and intentionally left open for further examination, was found almost completely infilled in 2015, and the ridge morphology was modified by slumping of clasts down the slope and by reworking attributable to minor storm waves. In size, composition and overall condition, most of the clasts that filled the trench resemble reworked clasts from the ridge itself; only a small portion had been newly brought ashore. Second, a dark gray patina formed on the whitish exteriors of the carbonate clasts that had been excavated in 2013. These biologically weathered, darkened clasts had become indistinguishable from clasts that had been at the ridge surface for a much longer time.

The findings have two broader implications. First, coastal coarse-clast ridges respond not solely to major storms, but also to tropical storms or minor hurricanes. The modification and reworking of the ridge on Anegada most probably resulted from hurricane Gonzalo which was at category 1-2 as it passed about $60 \mathrm{~km}$ north of the island in October 2014. Second, staining of calcareous clasts by cyanobacteria in the supralittoral zone occurs within a few months. In this setting, the degree of darkening quickly saturates as a measure of exposure age.
\end{abstract}

\section{Introduction}

This note documents short-term modifications of modern coarse-clast storm deposits that line part of the north shore of Anegada, British Virgin Islands. Anegada is a low-lying Caribbean island that faces the Puerto Rico Trench (Fig. 1). Nowhere more than $9 \mathrm{~m}$ a.s.l. (above sea level), the island is composed mainly of Pleistocene limestone and is fringed by sandy beach ridges and, locally, by a coral-rubble ridge that forms the island's coarsest deposits of modern storms. The rubble ridge hugs the island's central north shore, which faces the open Atlantic Ocean and is sheltered by a fringing reef which reduces the height of swell significantly. While the sandy shores on the western side of the island are subject to human modification, e.g. construction of beach houses, the central and eastern part of Anegada's north shore is very remote, can only be reached by foot, and is untouched by any anthropogenic activities. The ridge was found to extend discontinuously for $1.5-1.8 \mathrm{~km}$ along the shore (for detailed maps see Spiske and Halley, 2014). Its sedimentology was first surveyed in March 2013 along two transects (Spiske and Halley, 2014). A trench along one of these transects (transect II) was intentionally left open to be able to better detect any, even small-scaled, changes of ridge morphology or any other type of modification by surface processes, weathering or later inundation events (Fig. 2a and b).

Nearly two years later, in February 2015, additional field work revealed that the trench had been partly filled with coral rubble (Fig. 2c and d). This was unexpected because no strong hurricane and related surge had affected Anegada in the interim. 


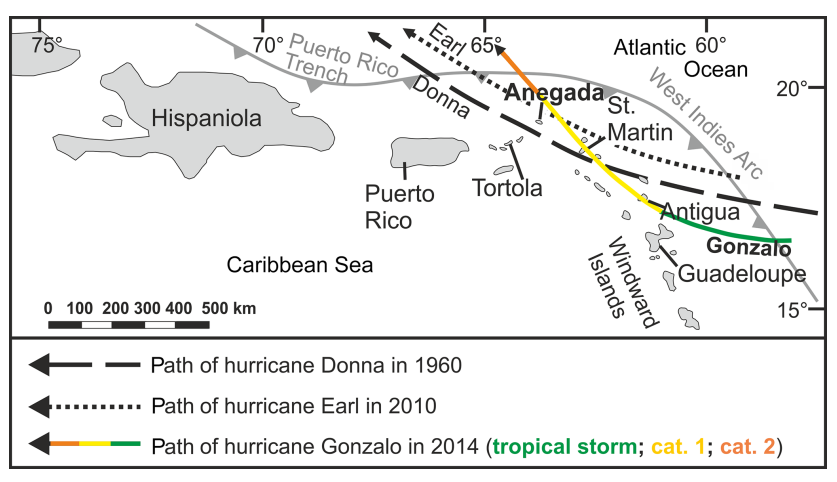

Figure 1. Location of Anegada and tracks of hurricane Donna (1960), Earl (2010) and Gonzalo (2014) that affected the island with different consequences in terms of storm surge inundation and sediment emplacement.

Here, the material that newly infills the trench is documented and compared with the composition of the ridge in 2013. It is asked if the clast size, type, and source of the new material are similar to the ridge composition in 2013. In addition, the degree and rapidness of surface weathering is addressed. These findings, give insights into the magnitude of inundation processes that can entrain and transport the respective material, and modify an existing ridge or build a new ridge.

\section{Hurricanes on Anegada}

The risk of hurricane-related storm surges inundating the low-lying coast of Anegada is discussed by Spiske and Halley (2014) and Atwater et al. (2012, 2014). Most notable surges and large swell that affected Anegada in the last decades were related to hurricane Donna in 1960 and Earl in 2010 (Fig. 1; Table 1).

Hurricane Donna passed about $15 \mathrm{~km}$ south of Anegada on 5 September 1960 with wind speeds of 115-120 knots, attaining category 3-4 (Dunn, 1961; National Oceanic and Atmospheric Administration, 2012; Fig. 1; Table 1). Eyewitness accounts suggest that Donna's trailing-left quadrant produced a $2.5 \mathrm{~m}$ storm surge on Anegada's south shore (Atwater et al., 2012). The storm's effects on the north shore are unknown.

Hurricane Earl passed about $30 \mathrm{~km}$ north of Anegada on 30 August 2010 as a category 4 hurricane with wind speeds of up to 115 knots (Cangialosi, 2011; Fig. 1; Table 1). Wrack lines were surveyed in 2011 at maximum elevations of $1.5 \mathrm{~m}$ a.s.l. from surge near the low-lying south shore and $2.0 \mathrm{~m}$ a.s.l. from surge and wash on the north shore (Atwater et al., 2014). The storm also suspended microbial matter in salt ponds of the island's interior. On the south shore, sand and lime mud as much as $10 \mathrm{~cm}$ thick were deposited on a sandy spillover fan that extends a few tens of meters inland
Table 1. Parameters of hurricanes Donna, Earl and Gonzalo at their closest position to Anegada.

\begin{tabular}{lllrr}
\hline Name & Date & $\begin{array}{l}\text { Distance from } \\
\text { Anegada }\end{array}$ & Category & $\begin{array}{r}\text { Wind speed } \\
\text { (knots) }\end{array}$ \\
\hline Donna & 5 Sep 1960 & 15 km south & $3-4$ & $115-120$ \\
Earl & 30 Aug 2010 & 30 km north & 4 & 115 \\
Gonzalo & 14 Oct 2014 & 60 km north & $1-2$ & 90 \\
\hline
\end{tabular}

(Atwater et al., 2014). Along the north shore sand was eroded and transferred into the sea.

The only noteworthy event that happened between the surveys in March 2013 and February 2015 was hurricane Gonzalo (Fig. 1; Table 1). It passed Anegada with wind speeds of 90 knots, as a category 1-2 hurricane, $\sim 60 \mathrm{~km}$ to its north on 14 October 2014 (Brown, 2015). Before reaching Anegada, Gonzalo made landfall on Antigua and St. Martin where waves and storm surge caused major damage to harbors and coastal structures (Brown, 2015). No severe impact was reported from Anegada.

\section{Methods}

The ridge was re-surveyed using the methods described in Spiske and Halley (2014). The trench was hand-dug from the mean tide level to the landward limit of the ridgeforming rubble, which apparently terminates at dense vegetation (Fig. 2a). For each of the 708 clasts in the former trench, long, intermediate, and short axes were measured, the clast type was determined, and angularity, roundness, karstification, encrustation, and borings were documented. After clearing the trench from any newly deposited clasts, the ridge thickness was measured with a tape measure in order to detect thickness changes between 2013 and 2015 (Fig. 3). The thickness of the infill was calculated by subtracting the height difference of the surface of the ridge filling from the ridge surface at the sides of the trench.

\section{Characteristics of the ridge in 2013}

When surveyed in March 2013 (Spiske and Halley, 2014), the ridge at transect II started at a distance of $8.6 \mathrm{~m}$ from the mean tide level and continued to $23.5 \mathrm{~m}$ inland, for a width of $14.9 \mathrm{~m}$. The maximum thickness at the ridge crest was $0.8 \mathrm{~m}$. The seaward side was steep. The ridge was composed of well-rounded clasts $(96 \%)$ with an average clast size of $16 \times 11 \times 4 \mathrm{~cm}$, the biggest clast was $75 \times 40 \times 5 \mathrm{~cm}$. Main components (Fig. 4a) of the clast-supported ridge were corals $(61 \%)$, reef rock $(28 \%)$, conch shells $(5 \%)$, serpulite rock $(4 \%)$, beach rock ( $1 \%)$, and Pleistocene limestone (1\%). The coral species present (Fig. 4b) were Acropora (49\%; A. palmata and A. cervicornis), Diploria (26\%; Diploria sp. and D. labyrinthiformis), Montastrea (17\%; 

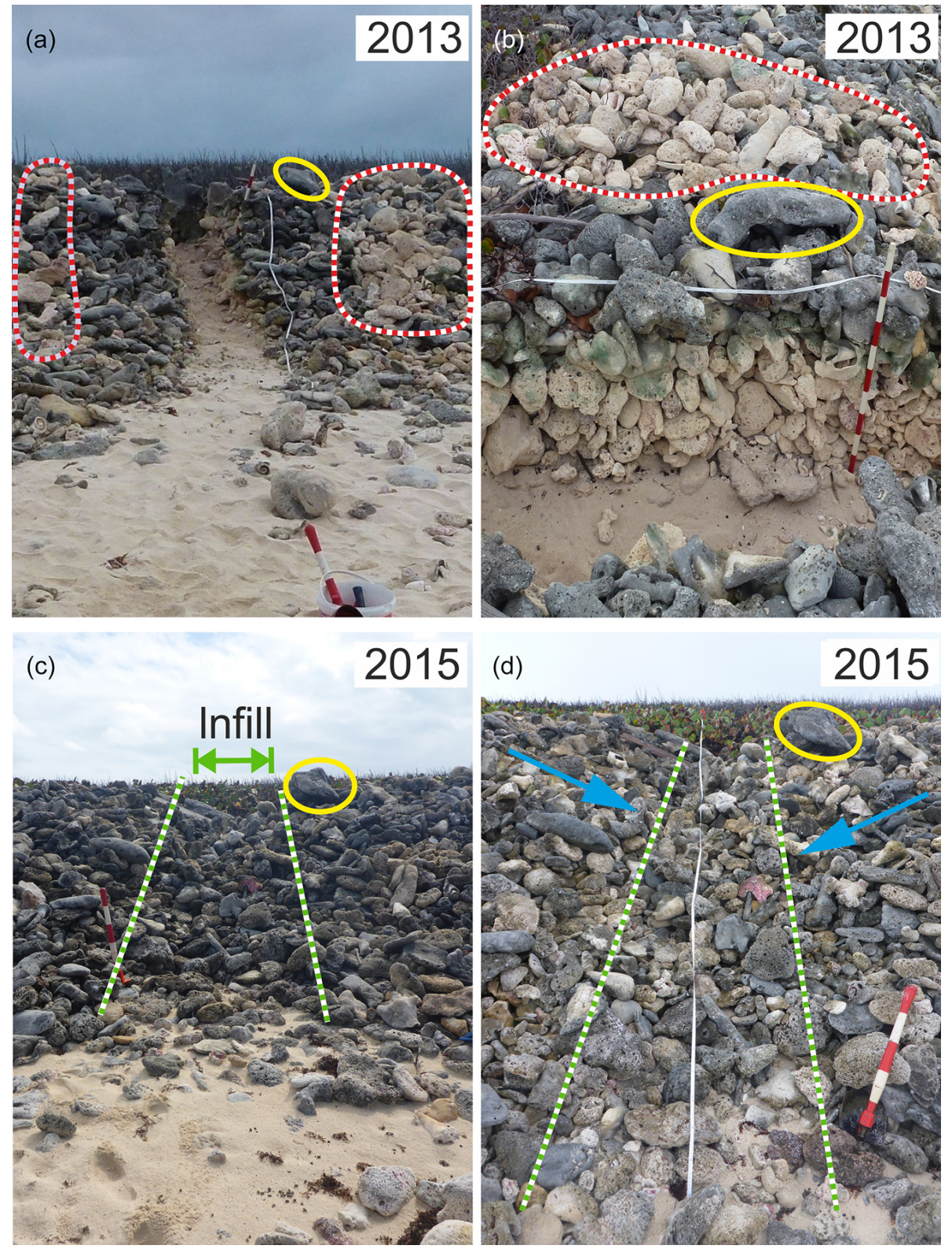

Figure 2. Comparison of transect II (a, b) in 2013 and (c, d) in 2015. (a, b) The trench is free of any clasts in 2013. Clasts that were moved when the trench was dug are covering the ridge to its left and right side, depicting a fresh bright surface (area is circled in white and red) in contrast to the clasts that were exposed to surface weathering processes before 2013. (c, d) Infill of the trench as encountered in 2015 (white and green lines confine the sides of the former trench). (c) Dark grey surface of the ridge in 2015; the bright material moved in 2013 is no longer distinguishable, i.e. already strongly weathered within the elapsed two years. (d) Detailed view of the material that newly infills the trench, leaving only a linear depression that coincides with the former trench. The blue arrows indicate slumping of the upper parts of the former walls into the trench. For orientation, the location of a large Acropora coral that has not been moved, is marked by a yellow circle in all photos.

Montastrea sp. and M. cavernosa), Porites $(6 \%)$ and Milleporida $(2 \%)$. About $80 \%$ of the clasts were encrusted with Homotrema rubrum (Lamarck) or bored. Sand was only present in the lowermost $\sim 5 \mathrm{~cm}$ of the ridge. Some flattened clasts were imbricated in a direction that suggested emplacement as bed load during unidirectional landward flow.
Spiske and Halley (2014) referred the emplacement of the ridge to hurricanes stronger than hurricane Earl (category 4) in 2010 because no new ridge was formed, and the preexisting ridge was not significantly altered during the event. Earl was only capable of slightly reworking the lower sea- 


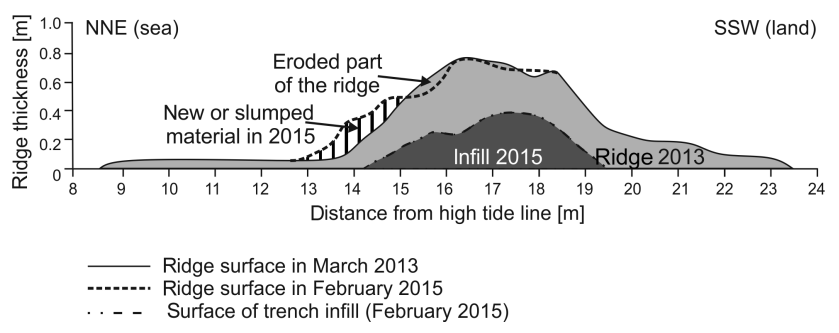

Figure 3. Comparison of the ridge thickness and morphology (at transect II) in March 2013 and February 2015. In the interim the trench dug at transect II had been partly refilled with $\sim 0.74 \mathrm{~m}^{3}$ of material.

ward parts of the ridge and of transporting few small pieces of coral rubble onshore.

\section{Characteristics of the ridge in 2015}

The position of the seaward onset and landward termination of the ridge had not changed since 2013. Its maximum thickness was still $0.8 \mathrm{~m}$ at a distance of $\sim 16 \mathrm{~m}$ from the mean tide limit. However, the morphology of the seaward slope and top of the ridge had changed (Fig. 3). Where the slope was relatively uniformly steep in 2013, the slope in 2015 exhibited two obvious steps (at $\sim 13.9$ and $14.8 \mathrm{~m}$ from the shore). Close to its top (at $\sim 15.5 \mathrm{~m}$ from the shore), the thickness of the ridge in 2015 was $\sim 10 \mathrm{~cm}$ less than in 2013. In contrast, the thickness in the lower half of the seaward side $(\sim 13.5-$ $14.8 \mathrm{~m}$ from the shore) locally increased by $20-25 \mathrm{~cm}$.

The material found infilling the trench started at $\sim 9.2 \mathrm{~m}$ from the shore, about $0.6 \mathrm{~m}$ farther inland than the ridge itself (Fig. 3). The maximum thickness of the infilled material was $0.4 \mathrm{~m}$ at $\sim 17.5 \mathrm{~m}$ from the shore. The morphology of the infill paralleled the surface of the current ridge, with a break in slope roughly in the middle of the seaward flank. In total 708 clasts were measured and the total volume of the infilled clasts amounts to $\sim 0.74 \mathrm{~m}^{3}$. The average clast size was $15 \times 10 \times 5 \mathrm{~cm}$, and the biggest clast in the infill was a piece of Acropora palmata $(86 \times 60 \times 15 \mathrm{~cm})$. About $63 \%$ of the clasts were encrusted with Homotrema rubrum (Lamarck) and $96 \%$ were well-rounded. The main components (Fig. 4a) were corals $(78 \%)$, reef rock $(7 \%)$, conch shells $(6 \%)$, Pleistocene limestone $(4 \%)$, serpulite rock $(2 \%)$, beach rock $(1 \%)$, gastropods $(1 \%)$ and other material (1\%; e.g. wood, flip flops). The coral species represented (Fig. 4b) were Acropora sp. (74\%), Diploria sp. (12\%), Porites (7\%), Montastrea sp. (2\%), Siderastrea (2\%), Milleporida (2\%) and Gorgonia (1\%). No sand was present in the interstices of the coarse-clast framework of the ridge.

Neither sedimentary structures, nor systematic vertical or lateral trends in particle size were observed in the trench infill. However, low-density clasts such as serpulite rock, wood, flip flops, Gorgonia and Milleporida were found higher and farther inland, on average, than were the relatively dense clasts of Pleistocene limestone, beach rock and Montastrea.

\section{Discussion}

Field observations and analytical data clearly show a modification of the ridge and the infilling of the trench during the 23 months that elapsed since the initial survey by Spiske and Halley (2014). However, these changes were unexpected considering the short time period and the fact that the island was not affected by any severe wave conditions in the meantime. Thus, modifications seem to underlie much weaker energetic processes, and bioweathering of fresh clast surfaces seems to already occur within a few months. There are no signs of any human modification of the ridge.

\subsection{Bioweathering}

The material that was manually moved during the excavation of the trench was apparent because of its light color in 2013 (Fig. 2a and b). The light color was a consequence of burial that had inhibited weathering by surface processes such as sea spray or lithobiontic weathering (Spiske and Halley, 2014). In 2015 these manually moved clasts were no longer distinguishable (Fig. 2c) because weathering had already darkened their surfaces.

Colonization by epi- and endolithic cyanobacteria (bluegreen algae) is an inevitable process that affects coastal sites (Golubic et al., 1980). The rubble ridge at Anegada is positioned in the supralittoral zone, often being wetted by sea spray, as well as by wave splash during storms. This ecological niche is a preferred living environment of cyanobacteria (Radkte et al., 1997; Spencer and Viles, 2002; Gómez-Pujol et al., 2006). The rate of colonization is a function of the temperature, and of the exposure to insolation, waves, spray or splash water (e.g. Folk et al., 1973; Radkte et al., 1997; Schneider and Le Campion-Alsumard, 1999). The activity of the cyanobacteria causes a dark grey to black coating (biopatina) on the clast surfaces and a few micrometers to millimeters deep (e.g. Folk et al., 1973). Porous, bored or karstified rocks, such as the coral and limestone clasts on Anegada, promote the colonization by endolithics (Hoppert et al., 2004). However, endolithic colonization rates are much slower compared to epilithics (e.g. Viles, 1987; Hoppert et al., 2004; McNamara et al., 2006). Under ideal conditions, colonization rates can be extremely rapid with initial occupation of fresh surfaces within 8-9 days of exposure and a complete overgrowth in three weeks to less than four months (Spencer (1988); and references therein). Spencer (1988) notes that colonization leaves the initially fresh surface visually indistinguishable from the surrounding surfaces. This indeed applies for the surfaces of the clasts on Anegada that 

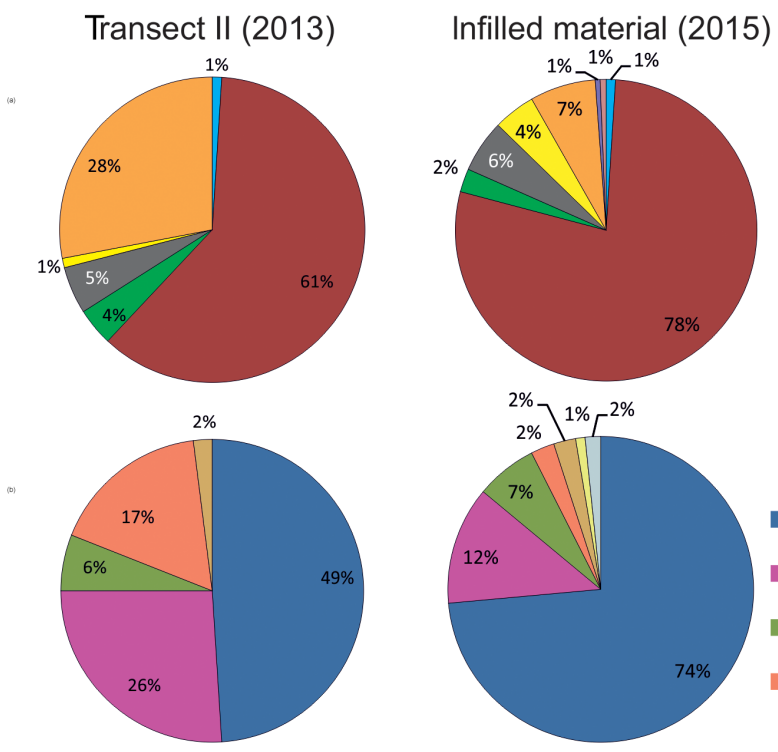

- Beach rock

- Corals

- Serpulite rock

- Conch shells

- Pleistocene limestone

- Reef rock

- Gastropods

- Other (wood, flip flops)

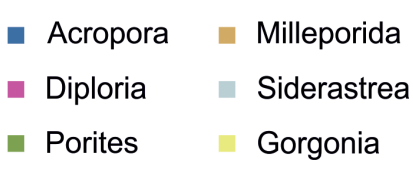

Montastrea

Figure 4. (a) Percentage of each component and (b) percentage of each coral species of the trench in 2013 and the new trench infill in 2015.

were manually moved and put onto the ridge in 2013 that were no longer distinguishable 23 months later (Fig. 2a-c). Warscheid and Braams (2000) reported that freshly quarried stone could be covered by biofilms within months. On the Aldabra Atoll (Indian Ocean), a tropical setting similar to Anegada, Whitton and Potts (1979) documented that supralittoral beach rock which was newly exposed by coastal erosion already had a light steel-blue color caused by bluegreen algae within two weeks after exposure. This report is underlined by Folk et al. (1973) who state that algae coatings grow fastest and cover is more dense and abundant in tropical humid climates with high temperatures and in settings with constant wetting by sea spray or splash. Thus, it is not surprising after all, that algae would have darkened the lightcolored clasts removed from the trench the next two years. In that case, the surface color of calcareous clasts in tropical climate settings, like Anegada, quickly saturates as a guide to the duration of clasts exposure, i.e. relative dating of ridge emplacement.

In close-up view, the infilled material and the ridge surface in 2015 show a mixture of clasts with light and dark gray (bioweathered) surfaces (Fig. 2d). This distribution results from (i) mixing of weathered and fresh rubble and (ii) overturning of the ridge-derived clasts during transport. The ridge-derived clasts exhibit at least one darkened side, previously being exposed at the ridge surface, and brighter sides that were not directly exposed to spray, splash and insolation. Assuming that hurricane Gonzalo emplaced the clasts in mid October 2014, four months passed until the survey in February 2015. At the time of the survey the clast surfaces of the moved material were still light-colored and did not yet show signs of darkening by biofilms. Consequently, at the given conditions on Anegada, the minimum time for algal colonization is $>4$ months. Contrariwise, the maximum colonization time is less than 23 months because clasts that were artificially moved when the trench was dug in March 2013 were no longer distinguishable from longer exposed clasts in February 2015.

\subsection{Ridge composition}

Most obviously the trench dug in 2013 was nearly completely infilled (Fig. 2c) and the minor depression as the only visible remain of the previous trench (Fig. 2d) was hard to detect in 2015. Detailed analyses of the trench infill document an average clast size of $15 \times 10 \times 5 \mathrm{~cm}$, which is very similar to the average clast size in $2013(16 \times 11 \times 4 \mathrm{~cm})$. Likewise, the degree of reworking and encrustation (up to $96 \%$ ) of the clasts is very high both in 2013 and 2015. The main components that constitute the ridge in 2013 and its infill in 2015 are corals, conch shells, Pleistocene limestone, serpulite rock, and minor portions of reef rock and beach rock (Fig. 4a). The same applies for the main coral species (Acropora, Diploria, Porites, Montastrea; Fig. 4b). The percentages of each component and coral species shifted, but the overall composition did not change significantly, even though some minor constituents like Gorgonia, Siderastrea and gastropods were only counted during one of the surveys. The deviation in percentage and the occurrence of some species in just one of the surveys may be the result of spatial variations in ridge composition. Spiske and Halley (2014) presented these variations when comparing transects I and II.

The composition of the ridge and the infilling of the trench do not significantly differ. This implies that (i) either the source of the material remained the same and still provided 
sufficient material for the infilling, or (ii) the ridge itself provided (portions of) the material as it was partly reworked by swell, most probably related to the passage of hurricane Gonzalo in October 2014.

\subsection{Ridge modification and emplacement}

Infilling of the trench was only possible during a storminduced surge that allowed waves to overtop the $\sim 1-1.5 \mathrm{~m}$ high coastal platform along Anegada's central north coast (for a detailed view of the platform see Figs. $2 \mathrm{a}$ and $3 \mathrm{a}$ in Spiske and Halley, 2014). Even during rough sea conditions, with offshore wave heights $>2.5 \mathrm{~m}$, as observed during the survey in 2015, the fringing reef and the shallow lagoon effectively decrease wave heights, not allowing for an inundation of the coastal platform. Consequently, only a storm surge, i.e. an elevated wedge of water pushed towards the coast, on top of which the storm waves can propagate, enables waves to cross the shoreline and the small limestone platform.

The clast-supported framework of the ridge with interlocking components is quite stable. However, storm wave action will at least rework the loose clasts on the surface of the seaward flank of the ridge. At the transect site, material from the uppermost parts of the ridge was eroded and either transported downslope or slumped into the excavated trench. Slumping of clasts from the upper trench walls into the trench may vaguely be observed in Fig. 2 d. Nevertheless, it remains unknown which portions of the $\sim 0.74 \mathrm{~m}^{3}$ of infilled material were newly entrained in the shallow marine environment and which derive from reworking of the ridge. If a significant number of clasts was entrained and transported onshore, clasts with all surfaces being unweathered should be found all along the ridge. However, as nearly all clasts have one dark side, it is assumed that reworking of ridge material is the dominant process.

Spiske and Halley (2014) assumed that the rubble ridge was emplaced during a hurricane-related inundation event which was most probably more energetic in terms of surge height, wave speed and wave amplitude, than hurricanes Earl and Donna. However, less energetic storm conditions account for the infilling of the trench that occurred between March 2013 and February 2015. The largest storm at Anegada in that interval was hurricane Gonzalo, which passed about $60 \mathrm{~km}$ north of Anegada in October 2014 (category 12). Nevertheless, since most of the infill seems to represent eroded ridge material and only a small portion of fresh material was added, it can be referred that such a weak event may not create a ridge, due to the lack of energy to transport clasts onshore, but at least modify a preexisting ridge. Consequently, coarse-clast ridges are vulnerable to even small storms and thus ridge systems are highly dynamic. This conclusion is underlined by a recent study of $\mathrm{Xu}$ et al. (2015) who sampled the coarse-clast ridge on Anegada to create a 20th century coral calibration. They counted the growth bands and used uranium-series dating to determine the duration of coral growth represented by two coral clast samples. The end of growth, i.e. timing of the entrainment of the coral and its subsequent death, were dated as $\mathrm{AD} 1953.3 \pm 0.72$ and $\mathrm{AD} 1989.5 \pm 0.58$, respectively. Of course, these are only two samples, however they show that clasts were most probably added to the preexisting ridge at least for decades. No notable hurricanes are documented to have passed Anegada at the respective times, again pointing to the fact that even minor storm events are capable of adding material to the ridge.

Future storm impact on Anegada should be monitored in greater detail to get information on parameters that can govern the characteristics of hurricane-related inundations, amongst others, the role of the hurricane intensity, distance to the island, alignment of the storm track relative to the island, or direction of swell (Gardener et al., 2005). These factors can influence the surge height and the clast transport capacity of the waves, and under particular conditions even tropical storms or category 1-2 hurricanes may cause severe coastal damage, whereas in turn the effectiveness of category $>2$ storm may be attenuated by factors such as swell direction or alignment of the storm track relative to the island.

\section{Conclusions}

The coral-rubble ridge along Anegada's central north coast that was initially surveyed in 2013 underwent morphological changes in the subsequent 23 months. A trench that has been dug through the ridge and left open in 2013 was found nearly completely infilled with clasts in 2015. Light-colored clasts placed on the ridge surface in 2013 were found bioweathered and darkened in 2015. These comparisons suggest:

- modification and emplacement of coarse-clast coastal ridges occurs already at lower wave energy levels;

- minor hurricane-induced surges mainly rework preexisting ridge structures, adding only few freshly entrained marine components;

- under the prevailing (supralittoral) conditions, colonization by cyanobacteria that cause staining of the clast surfaces takes at least 4 months, but less than 23 months;

- in a tropical climate context, blackening of calcareous clasts by biopatina saturates in less than two years as a measure of exposure time of calcareous deposits.

Acknowledgements. This study is part of the US Geological Survey's "Tsunami Hazards Potential in the Caribbean" project. I thank Brian Atwater, Anna Lisa Cescon, Robert Halley and Jean Roger for support in the field and during manuscript preparation. J. Roger helped to measure $>700$ clasts. 
Edited by: J. Roger

Reviewed by: two anonymous referees

\section{References}

Atwater, B. F., ten Brink, U. S., Buckley, M., Halley, R. B., Jaffe, B. E., López-Venegas, A. M., Reinhardt, E. G., Tuttle, M. P., Watt, S., and Wei, Y.: Geomorphic and stratigraphic evidence for an unusual tsunami or storm a few centuries ago at Anegada, British Virgin Islands, Nat. Hazards, 63, 51-84, 2012.

Atwater, B. F., Fuentes, Z., Halley, R. B., Ten Brink, U. S., and Tuttle, M. P.: Effects of 2010 Hurricane Earl amidst geologic evidence for greater overwash at Anegada, British Virgin Islands, Adv. Geosci., 38, 21-30, doi:10.5194/adgeo-38-21-2014, 2014.

Brown, D. P.: Tropical cyclone report Hurricane Gonzalo (AL082014) 12-19 October 2014: National Hurricane Center, p. 30, http://www.nhc.noaa.gov/data/tcr/AL082014_ Gonzalo.pdf, last access: August 2015.

Cangialosi, J. P.: Tropical cyclone report Hurricane Earl (AL072010) 25 August-4 September 2010: National Hurricane Center, p. 29, http://www.nhc.noaa.gov/data/tcr/ AL072010_Earl.pdf (last access: August 2015), 2011.

Dunn, G. E.: The hurricane season of 1960, Mon. Weather Rev., 89, 99-108, 1961.

Folk, R. L., Roberts, H. H., and Moore, C. H.: Black phytokarst from Hell, Cayman Islands, British West Indies, Geol. Soc. Am. Bull., 84, 2351-2360, 1973.

Gardner, T. A., Côté, I. M., Gill, J. A., Grant, A., and Watkinson, A. R.: Hurricanes and Caribbean Coral Reefs: Impacts, Recovery Patterns, and Role in Long-Term Decline, Ecology, 1, 174-184, 2005.

Golubic, S., Friedmann, E. I., and Schneider, J.: The lithobiontic ecological niche, with special reference to microorganisms, J. Sediment. Petrol., 51, 475-478, 1980.

Gómez-Pujol, L., Fornós, J. J., and Swantesson, J. O. H.: Rock surface millimetre-scale roughness and weathering of supratidal Mallorcan carbonate coasts (Balearic Islands), Earth Surf. Proc. Land., 31, 1792-1801, 2006.
Hoppert, M., Flies, C., Pohl, W., Günzl, B., and Schneider, J.: Colonization strategies of lithobiontic microorganisms on carbonate rocks, Environ. Geol., 21, 183-191, 2004.

McNamara, C. J., Perry, T. D., Bearce, K. A., Hernandez-Duque, G., and Mitchell, R.: Epilithic and endolithic bacterial communities in limestone from a Maya archaeological site, Microb. Ecol., 51, 51-64, 2006.

National Oceanic and Atmospheric Administration: Historical hurricane tracks, http://www.csc.noaa.gov/hurricanes/\# (last access: August 2015), 2012.

Radtke, G., Le Campion-Alsumard, T., and Golubic, S.: Microbial assemblages involved in tropical coastal bio-erosion: an Atlantic-Pacific comparison, Proceedings of the 8th International Coral Reef Symposium, 24-29 June 1996, Panama City, 1825-1830, 1997.

Schneider, J. and Le Campion-Alsumard, T.: Construction and destruction of carbonates by marine and freshwater Cyanobacteria Eur. J. Phycol., 34, 417-42, 1999.

Spencer, T.: Limestone coastal morphology: the biological contribution, Prog. Phys. Geogr., 12, 66-101, 1988.

Spencer, T. and Viles, H.: Bioconstruction, bioerosion and disturbance on tropical coasts: coral reefs and rocky limestone shores, Geomorphology, 48, 23-50, 2002.

Spiske, M. and Halley, R. B.: A coral-rubble ridge as evidence for hurricane overwash, Anegada (British Virgin Islands), Adv Geosci., 38, 9-20, doi:10.5194/adgeo-38-9-2014, 2014.

Viles, H. A.: Blue-green algae and terrestrial limestone weathering on Aldabra Atoll: a SEM and light microscope study, Earth Surf. Proc. Land., 12, 319-330, 1987.

Warscheid, T. and Braams, J.: Biodeterioration of stone: a review, Int. Biodeterio. Biodegrad., 46, 343-368, 2000.

Whitton, B. A. and Potts, M.: Blue-green algae (cyanobacteria) of the oceanic coast of Aldabra, Atoll Res. Bull., 238, 1-9, 1979.

$\mathrm{Xu}$, Y., Pearson, S., and Kilbourne, K.: 2015, Assessing coral $\mathrm{Sr} / \mathrm{Ca}-\mathrm{SST}$ calibration techniques using the species Diploria strigosa, Palaeogeogr. Palaeocl., 440, 353-362, 2015. 